\title{
INTERNAL FACTORS INFLUENCING COMMERCIAL BANKS' LENDING BEHAVIOUR IN MALAYSIA
}

\author{
Mohamad Azwan Md Isa ${ }^{1}$ \\ Faculty of Business Management, Universiti Teknologi MARA (UiTM), Malaysia. \\ (Email: moham821@uitm.edu.my) \\ Ruziah A Latif ${ }^{2}$ \\ Faculty of Business Management, Universiti Teknologi MARA (UiTM), Malaysia. \\ (Email: ruzia418@uitm.edu.my) \\ Zaibedah Zaharum ${ }^{3}$ \\ Faculty of Business Management, Universiti Teknologi MARA (UiTM), Malaysia. \\ (Email: zaibe101@uitm.edu.my) \\ Ferri Nasrul $^{4}$ \\ Faculty of Business Management, Universiti Teknologi MARA (UiTM), Malaysia. \\ (Email: ferri@uitm.edu.my) \\ Mohd Khairul Ariff Noh $^{5}$ \\ Faculty of Business Management, Universiti Teknologi MARA (UiTM), Malaysia. \\ (Email: ariff890@uitm.edu.my)
}

Received date: 17-11-2019

Revised date: 19-11-2019

Accepted date: 20-11-2019

Published date: 15-12-2019

To cite this document: Isa, M. A. M., Latif, R. A., Zaharum, Z., Nasrul, F., \& Noh, M. K. A. (2019). Factors Influencing Commercial Banks' Lending Behaviour in Malaysia. Advanced International Journal of Banking, Accounting and Finance, 1 (1), 48-58.

DOI: $10.35631 /$ aijbaf.11005

\begin{abstract}
Commercial banks play a pivotal role as a financial intermediary in mobilizing funds among the sectors such as private households, business firms, and the government. Investment activities, business expansion, and industrial development depend largely on the funds, without which a country's economy will be stagnant and even worse the economy is going to be in catastrophe. Apparently, lending activity is the core business of commercial banks that contributes the largest income proportion to the banks. Therefore, this paper aims to examine the four specific internal factors influencing the commercial banks' lending behaviour. Sampling from the year 2009 to 2018, this study evidences that the volume of deposit, level of liquidity and bank size significantly influences the lending behaviour of commercial banks in Malaysia after the 2007/2008 global financial crisis. Specifically, the volume of deposit and non-performing loans negatively influence the banks' lending behaviour whereas the level of liquidity and bank size pose positive impacts on lending behaviour. These findings are very beneficial to the commercial banks, the Central Bank of Malaysia (BNM), depositors or shareholders as well as business firms in planning, formulating appropriate policies and ultimately making well-informed decisions in the future.
\end{abstract}


Keywords: Commercial Banks, Lending Behaviour, Volume of Deposit, Liquidity, NonPerforming Loan, Malaysia

\section{Introduction}

The growth and development of a country's economy depend largely on the funds available in the financial market. Besides raising capital through the stock market, business firms also obtain the funds by borrowing from the financial institutions particularly banks. Commercial banks play crucial function in the overall performance of an economy and the commercial banks have been at the centre of driving the economy as evidenced through the tremendous growth in the private sector credit over time (Olokoyo, 2011). Availability of funds through bank credit has boosted the expansion and productive investments in manufacturing, construction, property development, retailing and other economic sectors. The banks' ability in providing credit to the business firms will positively affect the business's efficiency, profitability and future growth.

The banking activities in Malaysia initially focused on trade and working capital financing, and foreign exchange remittances with London, India and China and primarily pertaining to non-ferrous metals particularly tin. In the early 1900s, the banking system continued to grow with more branches of foreign banks being opened. Local bank was then established by independent traders due to the rise of international trades in rubber and tin. Today, the banking industry is one of the crucial drivers in the economic development of the country. The Malaysian banking industry can be divided into two, namely conventional and Islamic banking systems, where the Central Bank of Malaysia (BNM) regulates and controls the banking systems to ensure the economic development of the country can be sustained.

Basically, commercial banks accept deposits, offer savings and current accounts, provide credit or loans and other financial services. The banks are the largest and most significant fund provider in the economy. Lending activity is the core activity and can be described as the heart of the commercial banks' business. Banks' credit helps to elevate firms' output level, expand investment capital and improve living standard of the society. The commercial banks accept deposits from clients with surplus fund while simultaneously using the fund to grant loans to deficit unit.

Malede (2014) suggests that loans and advances are the largest elements in the banks' asset portfolio and also the banks' predominant sources of income. Hence, it is important for the commercial banks to comprehend the factors that influence the banks' lending behaviour in order to maximize their productivity and performance. This is because the loans and advances constitute approximately $62 \%$ of the asset portfolio of the commercial banks. In addition, lending activity is the primary revenue driver for the commercial banks in Malaysia, which contributes roughly $70 \%$ of the commercial banks' working revenue.

In addition, it is crucial to understand the banks' lending behaviour because banking sector plays fundamental role in stimulating the economic growth and development (Maloba, 2018). With the latest development of market liberalization and globalization, the banks should be well prepared and more efficient in order to stay competitive (Cheong, 2000). Besides, the government should have better awareness about the factors that affect banks' lending behaviour. The BNM not merely influences the interest rates, but it also could direct the flow of credit to the economy's priority industries or sectors. In view that the commercial banks would respond directly to the changes in the availability of reserve funds or variation in the 
interest rate by changing their lending and investment portfolios, the BNM or government's financial measures would also pose impacts on the currency and deposit supply, loan availability, as well as the costs of money and loans in the multiple industries.

This study has its significance as we sample the data from the year 2009 to 2018 . We exclude the effects of 2007/2008 global financial crisis since during the two years, all sectors of economy particularly the financial sector had performed severely and this of course will cause unusual trend to our data that ultimately affects our test results. This study also attempts to confirm the findings revealed by Adzis, Sheng and Bakar (2018), who studied the determinants of Malaysian banks' lending using the samples from the year 2005 to 2014, which includes the period of 2007-2008 global financial crisis. The aim is to see whether there is any inconsistency in results if we exclude the effects of the 2007/2008 global financial crisis. Hence, this study will contribute the latest evidence of findings on the banks' lending behaviour in Malaysia besides enriching the existing literature.

The rest of this paper will be arranged as follows; the review of literature and development of hypotheses, the data sampling and methodology, the results and discussion, and the conclusion and recommendation.

\section{Review of Literature and Hypotheses Development}

The crucial indicator for the measurement of banks' lending behaviour is lending growth through monitoring the total loans and advances of the banks (Bhaumik, Dang \& Kutan, 2011; Louhichi \& Boujelbene, 2017). The development of bank lending is controlled by the supervisory authority of finance and banking as in the case of Vietnamese banking industry (Vo, 2018). This reflects the financial strength and soundness of the banks since the local authority determines the lending growth rate by relying on the evaluation of commercial banks' soundness.

Banks' lending behaviour is influenced positively by both the internal and external factors such as deposit volume, earnings after tax, bank's rate of interest, gross domestic product (GDP), inflation rate and reserve requirement in the case of Jordanian banks (Al-Kilani \& Kaddumi, 2015). Their study further added that the government's monetary policy tools negatively affect the banks' lending behaviour even though it shows insignificant impact. The notable point to highlight from their study is that the bank's lending behaviour is not significantly influenced by the bank's interest or lending rate. This finding is inconsistent with Karim, Azman-Saini, and Karim (2011) and Swamy (2012), who found significant negative impact of the lending rate on the banks' lending behaviour. Maloba (2018) and Vo (2018) suggested that banks' market capitalization and return on asset (ROA) influence the bank's lending behaviour whilst Cargill and Mayer (2006) proved that cash reserve requirement negatively affects the banks' lending behaviour.

Tomak (2013) reported that non-performing loan (NPL) negatively affects the lending behaviour of Turkish commercial banks. Malede (2014) showed that the NPL has significant impact on bank's lending behaviour of the Ethiopian banks. Amidu (2014) further added that high portion of the NPL on the banks' financial statement would dissuade the banks from extending the loans and consequently reduce the volume of lending by the banks. Rabab'ah (2015) revealed similar finding as in the case of the Jordanian commercial banks. Another study by Adzis et al. (2018) concluded that even though the NPL negatively influences the commercial banks' lending behaviour, but the NPL is proven not a significant factor. They 
added the NPL is merely one of the criteria used by the commercial banks to evaluate the customers' credit applications.

Customer's deposit is essential for the banks' lending activity as it provides large portion of fund resource for the banks to offer loans and advances to the public. Al-Kilani and Kaddumi (2015) suggested that banks in Jordan should attract more deposits from their customers. The volume of deposits significantly and positively affects banks' lending behaviour and credit allocations in Kenya (Maloba, 2018) and Nigeria (Matousek \& Solomon, 2018). Similar finding is revealed by Olusanya, Oyebo, and Ohadebere (2012) and Adzis et al. (2018). Further, Imran and Nishat (2013) noted that Pakistani banks with high volume of deposits would have higher liquidity and more capacity to provide loans. In India, Swamy (2012) also showed that customer' deposits influence the banks' lending positively regardless whether the economy is in the recession or not. Sarath and Pham (2015) suggested the higher deposit growth would facilitate the growth of banks' lending in Vietnam. Malede (2014) found that volume of deposit is insignificant influence towards bank' lending behaviour in Ethiopia.

Liquidity basically is described as the ability of bank to convert its short-term assets into cash with minimum loss. Liquidity is used to determine the effect of the proportional liquid assets held by the banks against the commercial banks' lending. Pruteanu-Podpiera (2007) discovered positive influence of the liquidity on the loan growth particularly in the situation of tight monetary policy. However, Rabab'ah (2015) revealed that a high liquidity maintained by the banks will reduce the banks' capacity to grant loans to the public. The studies by Amidu (2014), Mousa and Chedia (2016), and Adzis et al. (2018) also provide substantial evidences that the level of liquidity will affect banks' lending behaviour negatively. Meanwhile, Kim and Sohn (2017) concluded that the impact of an increase in bank capital on the credit growth that is positively associated with the liquidity level, is only applicable to the large banks.

Bank size is the most crucial and persistent factor to determine a bank's tendency to give loan in the Central African Economic and Monetary Community (Djiogap \& Ngomsi, 2012). Further, Malede (2014) and Amidu (2014) claimed that bank size positively affects bank lending behaviour. Rabab'ah (2015) concluded that the larger banks tend to provide larger credit facilities to the public in Jordan. In the context of European countries, Tomak (2013) also revealed that larger commercial banks in Turkey tend to provide more business loans to the public. In Russia, Chernykh and Theodossiou (2011) found that larger banks have more accessibility and larger fund to grant loans to the public. On the contrary, Pruteanu-Podpiera (2007) argued that the bank size tends to negatively affect the growth rate of loans in the Czech Republic.

Based on the literature review and previous studies, we have developed the four hypotheses. Hypothesis 1:

The non-performing loan (NPL) negatively influences the banks' lending behaviour Hypothesis 2:

The volume of deposits (DEP) positively influences the banks' lending behaviour

Hypothesis 3:

The level of liquidity (LIQ) negatively influences the banks' lending behaviour

Hypothesis 4:

The bank size (BSZ) positively influences the banks' lending behaviour 


\section{Data, Methodology and Hypotheses}

We have selected six Malaysian commercial conventional banks, namely Affin Bank Berhad, Alliance Bank Malaysia Berhad, Hong Leong Bank Berhad, RHB Bank, Maybank Berhad and Public Bank Berhad. The annual panel data covers from 2009 to 2018 and the data is gathered from the Eikon DataStream and the annual reports. Our test commences from the year 2009 because we want to examine the impacts and relationships of the selected variables post the 2007/2008 global financial crisis. The internal factors are the bank-specific variables namely non-performing loan, volume of deposit, level of liquidity, and bank size whilst the dependent variable is the total loans and advances of the six Malaysian commercial banks.

Total loans and advances (LOAN) refer to total annual gross loans and advances for both public and private sectors, which are obtained from the asset side of banks' balance sheet. NPL is a loan, where a borrower is default or not making interest payment or repaying principal for 90 days or more. The NPL is measured as a ratio to total loans and advances. DEP is one of the main sources of fund to the commercial banks to provide credit to the customers. The DEP is measured as a ratio to total assets. LIQ refers to total liquid assets to total assets ratio. BSZ is measured by the log total assets of the banks, where the total assets are obtained from the balance sheet at year end and become the base for the total resources available for commercial banks' business. The data is run in the EViews software and analysed using the descriptive analysis, correlation analysis and regression analysis. In this study, we use multiple variables and the equation is as follows:

$$
L O A N i t=\alpha+\beta 1 N P L i t+\beta 2 \text { DEPit }+\beta 3 L I Q i t+\beta 4 \ln B S Z i t
$$

In addition, we also run the f-test for model significance or specification. The hypotheses are as follows:

$$
\begin{aligned}
& \text { H0: } \beta 1 N P \text { Lit }=\beta 2 \text { DEPit }=\beta 3 \text { LIQit }=\beta 4 \ln B S Z i t=0 \\
& \text { H1: } \beta 1 N P \text { Lit } \neq \beta 2 \text { DEPit } \neq \beta 3 \text { LIQit } \neq \beta 4 \ln B S Z i t \neq 0
\end{aligned}
$$

\section{Results and Discussion of Findings}

\section{Descriptive Statistics}

Table 1: Descriptive Statistics Results

\begin{tabular}{lccccc}
\hline Variable & LOAN & NPL & DEP & LIQ & BSZ \\
\hline Mean & 0.6607 & 0.0216 & 0.8228 & 1.9786 & 18.7925 \\
Maximum & 0.7965 & 0.0700 & 0.8911 & 2.2180 & 20.5088 \\
Minimum & 0.4893 & 0.0048 & 0.7075 & 1.7593 & 17.1360 \\
\hline
\end{tabular}

Source: Datastream \& Banks’ Annual Reports

Table 1 shows the descriptive statistics. For the 10 years after the 2007/2008 global financial crisis, the six commercial banks in Malaysia had allocated $66.07 \%$ of their total assets to grant loans and advances. The highest total loans and advances is $79.65 \%$, which was recorded by Maybank Berhad (MBB) in 2015. As the largest commercial bank in Malaysia by total assets of USD195 billion as at December 31, 2018 and market capitalization of USD23 billion as at October 7, 2019 (Ratings, 2019), this result is not surprising and predictable. Meanwhile, the lowest total loans and advances was recorded by Hong Leong Bank (HLB) with $48.93 \%$ in 2009 and this was in the aftermath of the 2007/2008 global 
financial crisis, where most banks practiced high prudence and did not want to take high risk with over-lending since the Malaysian economy had just started to recover from the crisis.

The NPL results for the six commercial banks show preferable outcomes. The average value for NPL to total loans and advances is merely $2.16 \%$. This indicates that the selected commercial banks have good banking policy and are efficient in managing their loans and advances particularly in credit review and collection. Alliance Bank Malaysia Berhad had recorded the highest NPL with 7\% in 2009 due to the 2007/2008 global financial crisis, whereas Public Bank Berhad (PBB) had recorded the lowest NPL with 0.48\% in 2017. The result for $\mathrm{PBB}$ is expected and undeniable because the bank has been awarded with the best corporate governance practices for several consecutive years in Malaysia and Asian region. The average deposit volume is $82.28 \%$ out of total assets for the period from 2009 to 2018 .

This shows that customers' deposit constitutes significant portion of the banks' total assets and this implies that the banks depend on this source of fund to make investments or grant loans. The highest deposit is recorded by PBB with $89.11 \%$ in 2009 whilst MBB had the lowest percentage of deposit volume with $70.75 \%$ in 2016 in proportion to the total assets, respectively. PBB's highest percentage of deposit could be due to attractive interest offered and is attributable to customers' confidence in the bank's governance of their money.

The liquidity level also shows favourable results throughout the sample period. This is good because banks should have higher liquidity to be able to meet their short term obligations and to fulfil cash withdrawals requirement by the depositors. The highest liquidity was recorded by Alliance Bank in 2011 at 2.22 while the lowest was recorded by Hong Leong Bank (HLB) at 1.76 in 2011 as well. The lowest level of liquidity recorded by HLB could be due to the percentage change in total assets was greater than the percentage change in liquid assets.

The mean value for banks' size is 18.79 in log form or RM223,227,684,825 in nominal value. High asset ownership enables banks to offer more financial services at low cost. MBB recorded the largest bank size with RM806,991,681,000 or 20.51 in log form. This is good for MBB since large bank size could increase the profitability by allowing bank to realize economies of scale. The lowest bank size was recorded by Alliance Bank with 17.14 or RM27,674,926,000. This could be due to the bank's inefficiency in mobilizing the funds and generating profit from the funds.

\section{Pearson Correlation}

Table 2: Pearson Correlation Results

\begin{tabular}{lccccc}
\hline Variable & LOAN & NPL & DEP & LIQ & BSZ \\
\hline LOAN & 1.0000 & ----- & ----- & ---- & ---- \\
NPL & -0.3931 & 1.0000 & ----- & ---- & ---- \\
DEP & -0.4785 & -0.1301 & 1.0000 & ---- & ---- \\
LIQ & 0.2927 & -0.3557 & 0.1567 & 1.0000 & ----- \\
BSZ & 0.7354 & -0.3387 & -0.6790 & -0.0510 & 1.0000 \\
\hline
\end{tabular}

From Table 2, we could see that both NPL and DEP have negative correlations with LOAN, namely the total loans and advances. The p-values of NPL and DEP, which are less than 0.05 indicates the significance of both variables. The negative correlation of NPL answers our hypothesis 1 and this finding is consistent with Rabab'ah (2015), Amidu (2014) and Tomak 
(2013). The rationale is that when the banks have to allocate a high portion of their income towards NPL provision, this will discourage the credit delivery and reduce the lending capacity of the banks.

Meanwhile, the significant negative result of DEP is in line with the finding by SanfilippoAzofra, Torre-Olmo, Cantero-Saiz, and López-Gutiérrez (2018). The negative result implies that the six commercial banks in Malaysia are no longer depending on customers' deposits as a source for lending as the banks have broadened their sources of fund from other financial instruments such as bonds or sukuk and shares. Therefore, with this finding we have to reject our hypothesis 2 .

Whereas, LIQ and BSZ have positive correlations with total loans and advances. LIQ shows weak correlation whilst BSZ indicates quite strong correlation. Both LIQ and BSZ are also found to be significant variables to the total loans and advances based on the p-values that are less than 0.05 , respectively. The positive correlation of LIQ supports the finding by PruteanuPodpiera (2007), who concluded that liquidity positively affects the total loans and advances and this is particularly true when the government through the Central Bank decides to implement the contractionary monetary policy. However, the positive correlation of LIQ with the total loans and advances contradicts our hypothesis 3.

The results of BSZ are consistent with Rabab'ah (2015), who reveals that bank size positively influences total loans and advances and this finding answers our hypothesis 4. Apparently, the larger-size commercial banks tend to have more accesses to capital market or public capital and therefore larger funds to grant loans or advances to customers. Nonetheless, Pruteanu-Podpiera (2007) suggested that the banks' size negatively influences the loan growth.

From the Pearson correlation results, we could also see that NPL has negative correlation with the other three internal factors or independent variables. BSZ is also found to have negative correlation with DEP and LIQ. But, LIQ and DEP show positive correlation. The notable point to highlight is that there is no strong or very strong correlation among the variables since the coefficients are less than 0.8 and this is good to avoid any multicollinearity problem particularly when performing the multiple regressions.

\section{Multiple Regressions}

In regression analysis, the panel Ordinary Least Square (OLS) is used to test the variables and hypotheses. The results of multiple regressions are as shown in the following tables.

Table 3: Multiple Regressions Results

\begin{tabular}{lcccc}
\hline Variable & Coefficient & Std. Error & t-Statistic & Prob. \\
\hline C & -0.1683 & 0.4364 & -0.3858 & 0.7011 \\
NPL & -0.4081 & 0.6616 & -0.6169 & 0.5397 \\
DEP & -0.4838 & 0.2118 & -2.2849 & $0.0260^{*}$ \\
LIQ & 0.2727 & 0.0744 & 3.6640 & $0.0005^{*}$ \\
BSZ & 0.0370 & 0.0113 & 3.2745 & $0.0018^{*}$ \\
\hline
\end{tabular}

*Denotes 5\% significant level 


\section{T-test}

The results show that NPL and DEP negatively influence total loans and advances, whereas LIQ and BSZ positively influence the total loans and advances. These multiple regression results are consistent with the Pearson correlation results as presented in Table 2.

Referring to Table 3, NPL has no significant influence on total loans and advances whilst DEP, LIQ and BSZ have significant influence on total loans and advances. NPL is found to influence total loans and advances negatively with the coefficient of -0.4081 . It is interpreted that for every $1 \%$ increase in NPL, it will cause the total loans and advances to decrease by $0.4081 \%$ and vice versa. This finding supports the finding by Cheong (2000) and Tomak (2013), who revealed the negative impact of NPL on the banks' lending behaviour due to the fact that the banks need to allocate a high proportion of loan loss provision in order to curb the potential losses. In the wake of that, this will limit the commercial banks' capacity to grant loans or advances to public. Moreover, NPL insignificant result suggests that the six Malaysian commercial banks most probably do not take into consideration the NPL ratio as the main criteria to evaluate the loan application as claimed by Adzis et al. (2018). Furthermore, the level of NPL reported by the commercial banks is also very minimal throughout the sample period as we discussed in the descriptive analysis earlier.

Meanwhile, DEP shows negative significant influence on total loans and advances. The coefficient value of -0.4838 implies that when there is $1 \%$ rise in volume of deposit, it will result in $0.4838 \%$ fall in total loans and advances or vice versa. This finding is consistent with Sanfilippo-Azofra et al. (2018), who concluded that volume of deposit has negative relationship with total loans and advances. The six Malaysian commercial banks most probably no longer depend on customers' deposits as main source for their lending activities because the banks might have diversified their sources of funding to other areas for example bonds or sukuk, shares and unit trust funds. However, this finding is in contrast with Sarath and Pham (2015) and Matousek and Solomon (2018), who revealed positive influence of volume of deposit on commercial banks' lending behaviour. Based on their findings, the higher deposits placed by customers, the higher funds available for the banks to grant loans to public. This is, of course, a traditional or conventional way of generating funds for the commercial banks particularly among the less developed countries.

LIQ shows positive significant influence on total loans and advances. The coefficient of 0.2727 signifies that when there is $1 \%$ increase in level of liquidity, it will lead to the increase in total loans and advances by 0.2727 . This result supports the findings by Pruteanu-Podpiera (2007) and Díaz and Olivero (2010). However, Adzis et al. (2018) and Amidu (2014) proved contradicting result in their respective studies, which stated that liquidity negatively influences total loans and advances. Their rationale is that when the banks have to maintain a high proportion of funds in order to meet the short-term obligations such as withdrawal of money by depositors, it will reduce the commercial banks' ability to grant loans or credit facilities to customers. BSZ also poses positive significant influence on total loans and advances. The coefficient of 0.3070 indicates that when bank size changes by $1 \%$, total loans and advances will change by $0.3070 \%$. This finding is in support of Imran and Nishat (2013) and Olusanya et al. (2012). The finding justifies that larger banks tend to give more credit facilities to customers compared to smaller banks since larger banks have greater asset base and larger funds to grant loans. 


\section{F-test and R-squared}

Table 4: Multiple Regressions Results

\begin{tabular}{cccc}
\hline $\begin{array}{c}\text { R- } \\
\text { squared }\end{array}$ & $\begin{array}{c}\text { Adjusted } \\
\text { R-squared }\end{array}$ & $\begin{array}{c}\text { f- } \\
\text { Statistic }\end{array}$ & $\begin{array}{c}\text { Prob. } \\
\text { (f-Statistic) }\end{array}$ \\
\hline 0.5715 & 0.542 & 19.3402 & $0.0000^{*}$ \\
\hline
\end{tabular}

*Denotes $5 \%$ significant level

The F-statistic results show a critical value of 19.3402 and a p-value of 0.0000 , which indicates that the level of significance is lower than 5\%, therefore null hypothesis is rejected. It means that, at least one of the independent variables is useful in explaining the banks' lending behavior. In other words, we could say that the model is fit or the variables fit in the model. Further, the R-squared of 0.5715 indicates that $57.15 \%$ variation in total loans and advances is explained by the variations in NPL, DEP, LIQ and BSZ, whereas the remaining $42.85 \%$ of variation in total loans and advances is explained by other variables or factors, which are not included in this study.

\section{Conclusion and Recommendation}

In this paper, we investigate the relationships and influences of the four internal factors, namely NPL, DEP, LIQ and BSZ on the the six Malaysian commercial banks' lending behavior from 2009 to 2018. Both Pearson correlation and multiple regression results indicate that NPL and DEP have negative correlations or influences on banks' lending behavior for the period after the 2007/2008 global financial crisis. The finding on NPL is consistent with Adzis et al. (2018) whilst the negative finding of DEP contradicts. Whereas, LIQ and BSZ show positive correlations or influences on the commercial banks' lending behavior. The finding on BSZ supports Adzis et al. (2018), but the LIQ is conflicting with what they had revealed. Further, multiple regression results disclose the significance of DEP, LIQ and BSZ on the commercial banks' lending behavior. These findings call for the commercial banks to have effective policy to minimize the NPL and to have strong asset base (BSZ) because these two internal factors will influence the banks' lending behaviour significantly. Meanwhile, the policy maker in particular the BNM should formulate a policy in order for the the commercial banks to improve their liquidity as LIQ is also one of significant influnces on the banks' lending behaviour.

For future research, it is recommended to test other internal factors such as net income of the banks and reserve requirement as well as external factors like market interest rate, inflation rate and gross domestic product. Further study could also include qualitative factors such as the government monetary and fiscal policies tools, the central bank's rules and regulations and the commercial banks' policies. Other test techniques or methodologies such as logistic or probit regressions and co-integration and causality tests could also be employed in future study. Last but not least, the sample could include the banks from different regions or countries either from Asia or the Europe, developing or developed countries to see whether the influences on banks' lending behavior is consistent or conflicting among the countries.

\section{References}

Adzis, A. A., Sheng, L. E., \& Bakar, J. A. (2018). Bank Lending Determinants: Evidence from Malaysia Commercial Banks. Journal of Banking and Finance Management, $1(3), 36-48$. 
Al-Kilani, Q. A., \& Kaddumi, T. A. (2015). Cyclicality of Lending Behavior by Banking Sector for the Period (2000-2013): Evidence from Jordan. International Journal of Economics and Finance, 7(4), 57-65.

Amidu, M. (2014). What Influences Banks' Lending in Sub-Saharan Africa? Journal of Emerging Market Finance, 13(1), 1-42.

Bhaumik, S. K., Dang, V., \& Kutan, A. M. (2011). Implications of Bank Ownership for the Credit Channel of Monetary Policy Transmission: Evidence from India. Journal of Banking \& Finance, 35(9), 2418-2428.

Cargill, T. F., \& Mayer, T. (2006). The Effect of Changes in Reserve Requirements during the 1930s: The Evidence from Nonmember Banks. The Journal of Economic History, 66(2), 417-432.

Cheong, T. T. (2000). Commercial Banks' Lending and Economic Growth in Malaysia: An Empirical Study. Borneo Review: Journal of the Institute for Development Studies (Sabah), 11 (1), 60-71.

Chernykh, L., \& Theodossiou, A. K. (2011). Determinants of Bank Long-Term Lending Behavior: Evidence from Russia. Multinational Finance Journal, 15(3/4), 193-216.

Díaz, R. A., \& Olivero, M. P. (2010). On the Firm-Level Implications of the Bank Lending Channel of Monetary Policy. Journal of Economic Dynamics and Control, 34(10), 2038-2055.

Djiogap, C. F., \& Ngomsi, A. (2012). Determinants of Bank Long-Term Lending Behavior in the Central African Economic and Monetary Community (CEMAC). Review of Economics \& Finance, 107-114.

Imran, K., \& Nishat, M. (2013). Determinants of Bank Credit in Pakistan: A Supply Side Approach. Economic Modelling, 35, 384-390.

Karim, Z. A., Azman-Saini, W. N. W., \& Karim, B. A. (2011). Bank Lending Channel of Monetary Policy: Dynamic Panel Data Study of Malaysia. Journal of Asia-Pacific Business, 12(3), 225-243.

Kim, D., \& Sohn, W. (2017). The Effect of Bank Capital on Lending: Does Liquidity Matter? Journal of Banking \& Finance, 77, 95-107.

Louhichi, A., \& Boujelbene, Y. (2017). Bank Capital, Lending and Financing Behaviour of Dual Banking Systems. Journal of Multinational Financial Management, 41, 61-79.

Malede, M. (2014). Determinants of Commercial Banks' Lending: Evidence from Ethiopian Commercial Banks. European Journal of Business and Management, 6(20), 109-117.

Matousek, R., \& Solomon, H. (2018). Bank Lending Channel and Monetary Policy in Nigeria. Research in International Business and Finance, 45, 467-474.

Mousa, M., \& Chedia, H. (2016). Determinants of Bank Lending: Case of Tunisia. International Journal of Finance and Accounting, 5(1), 27-36.

Maloba, M. (2018). Determinants of Agri-Lending among Financial Institutions in Kenya. Thesis Master of Commerce in Development Finance, University of Cape Town.

Olokoyo, F. O. (2011). Determinants of Commercial Banks' Lending Behavior in Nigeria. International journal of financial research, 2(2), 61-72.

Olusanya, S. O., Oyebo, A., \& Ohadebere, E. (2012). Determinants of Lending Behaviour of Commercial Banks: Evidence from Nigeria, a co-integration analysis (1975-2010). Journal of Humanities and Social science, 5(5), 71-80.

Pruteanu-Podpiera, A. M. (2007). The Role of Banks in the Czech Monetary Policy Transmission Mechanism. Economics of Transition, 15(2), 393-428.

Rabab'ah, M. (2015). Factors Affecting the Bank Credit: An Empirical Study on the Jordanian Commercial Banks. International journal of Economics and Finance, 7(5), 166-178. 
Ratings, ADV (2019). Top Banks in Malaysia 2019 - Overview of Top 10 Banks. Retrieved from https://www.advratings.com/asia-pacific/top-banks-in-malaysia

Sanfilippo-Azofra, S., Torre-Olmo, B., Cantero-Saiz, M., \& López-Gutiérrez, C. (2018). Financial Development and the Bank Lending Channel in Developing Countries. Journal of Macroeconomics, 55, 215-234.

Sarath, D., \& Pham, D. V. (2015). The Determinants of Vietnamese Banks' Lending Behavior: A Theoretical Model and Empirical Evidence. Journal of Economic Studies, 42(5), 861-877.

Swamy, V. (2012). Financial Instability, Uncertainty and Bank Lending Behavior. International Journal of Banking and Finance 9(4), 74-95.

Tomak, S. (2013). Determinants of Commercial Banks' Lending Behavior: Evidence from Turkey. Asian Journal of Empirical Research, 3(8), 933-943.

Vo, X. V. (2018). Bank Lending Behavior in Emerging Markets. Finance Research Letters, 27, 129-134. 